\title{
Accounting
}

\section{Factors affecting job satisfaction of accountant and auditors at Hanoi auditing firms}

\author{
Hien Thu Nguyen ${ }^{a^{*}}$
}

${ }^{a}$ Academy of Finance, Vietnam

\section{H R O N I C L E}

\section{Article history:}

Received: August 23, 2020

Received in revised format:

October 302020

Accepted: November 16, 2020

Available online:

November 16, 2020

\section{Keywords:}

Job satisfaction

Hanoi auditing firms

Accountant and auditors

\begin{abstract}
A B S T R A C T
The article analyzes factors affecting job satisfaction of accountant and auditors at Hanoi auditing firms. For quantitative research methods, it is conducted through the collection of questionnaire survey data and processed by SPSS software to analyze data using the following techniques: Descriptive analysis, Cronbach's Alpha test, EFA exploratory analysis, multiple regression analysis. The research results show that the nature of work, relationships with leaders in the working process are the most influencing factors on the satisfaction of accountants and auditors in Auditing firms in Hanoi. From the research results of factors affecting the job satisfaction of accountants and auditors at auditing firms in Ha Noi, the author gives some recommendations to improve the level of job satisfaction, thereby improving the work quality of the accountants and auditors at the Hanoi auditing firms.
\end{abstract}

\section{Introduction}

In the context of today's increasingly extensive integration, one of the most important factors on the existence and development of an enterprise is to attract, build and maintain a team of high-quality, capable, enthusiastic and long-term employees. However, the phenomenon of "talent bleeding" has been happening in many businesses, the cause may be that the enterprises themselves cannot create job satisfaction for employees or the enticement of the enterprises. This is a problem that auditing firms in Hanoi are facing and facing many difficulties. The stabilization of human resources will help organizations and enterprises save costs such as training, recruitment, etc. and minimize possible professional errors, ensuring continuous development customs, stable and consistent, build trust and shape corporate culture (Yadav \& Dabhade, 2013). Several studies have shown that employee's job satisfaction has a positive effect on job performance (Iaffaldano \& Muchinsky, 1985), contributing to promoting employee's attachment to the team (Bowling et al., 2010). Furthermore, job satisfaction has a positive impact on employees' working attitude (Testa, 2001) and work motivation (Alam, 2012). Therefore, the analysis of factors affecting the employee's job satisfaction is very necessary for organizations and enterprises to develop and adjust personnel policies in the most appropriate way. The Vietnamese economy is integrating deeply, including the integration of a skilled workforce. Accordingly, foreign accounting and auditing specialists directly participate in Vietnam's accounting and auditing services more and more and easily, especially with the support of digital technology. Industry 4.0 also created the shift of information from books to digitalization, requiring each accountant and auditor to supplement and cultivate knowledge to match the digital movement of the whole platform economy. Therefore, auditing firms in Hanoi need to have a reasonable personnel policy to maintain high quality human resources, create job satisfaction for a long-term stay with the company. Stemming from the practical and essential needs of the * Corresponding author. E-mail address: hiennt@hvtc.edu.vn (H. T. Nguyen) 
above problem, this study aims to analyze the factors affecting job satisfaction of accountants-auditors at auditing companies in Hanoi to provide an analytical framework and suggest suggestions for human resource policy adjustments at an audit firm in Hanoi.

\section{Literature Review and research hypotheses}

\subsection{Literature Review}

The study of employee satisfaction plays an important effect on the performance and profitability of the organization. One of the most popular and widely applied studies in many fields is the Job Descriptive Index (JDI) model by Smith et al. (1969). This scale includes 5 factors: Job nature, Training and advancement opportunities, Leadership, Co-workers, and Salary. However, the JDI model also has some limitations such as: use of questionnaires with 72 questionnaires considered too long, making it difficult to investigate and collect data; The question-answer format in the original JDI model was Yes - No, so it is difficult to evaluate different levels of employee satisfaction; There is no question to assess overall employee satisfaction (Spector, 1997). Weiss et al. (1967), proposed the MSQ (Minnesota Satisfaction Quesionaire) model using one of two measures: the long scale, with 100 factors, each factor is measured by 5 variables; The table is shorter, with 20 factors assessing the overall satisfaction level of each aspect. However, the biggest disadvantage of MSQ is similar to JDI model is that the questionnaire is too long, if using a short table with 20 questions, the deviation is large and does not reflect the perception of staff. Spector (1997) built a separate JSS (Job Satisfaction Survey) model for employees in the service sector, including 9 factors for assessment of satisfaction and attitudes such as: Salary, Promotion opportunities, Working conditions, Supervision, Colleagues, Love Work, Communication, Surprise Rewards, and Benefits. In the study of the education sector at Community Universities in Pakistan, Malik et al. (2010) looked at the relationship between the components of job satisfaction and the degree of organizational engagement. The research results show that factors including Job Nature, Supervisory Quality, and Salary affect employees' job satisfaction and have a positive relationship with the degree of organizational engagement of employees. Staff. Parvin and Kabir (2011) built a research model on employee job satisfaction in the Medicine and Pharmacy industry including 7 influencing factors: Working conditions, Salary, Promotion, Career stability, Employment Equity, Relationship with Colleagues, and Relationship with Superiors. In Vietnam, Tran Kim Dung (2005) conducted a study to measure job satisfaction in Vietnamese conditions using Smith's job description index (JDI) and plus (1969), at the same time added two factors "Company welfare" and "Working conditions" to suit the specific situation in Vietnam. In the study on job satisfaction of employees in commercial banks in Hue, Phan Thi Minh Ly (2011) also pointed out the factors affecting job satisfaction. Including Nature and Working Pressure, Income and Remuneration, Relationships and Treatment, Bank Development Prospects and Leadership, Working Conditions, and Training and Promotion Opportunities.

\subsection{Research hypothesis}

This research model is designed based on the JDI model of Smith et al. (1969) combined with the studies of Spector (1997) and Tran Kim Dung (2005). In addition, through qualitative research (in-depth interviews and group discussions), the author proposes to add two new elements "Benefits" and "Working Environment" to the research model. Therefore, the article proposes the initial research model including the elements shown in Fig. 1.

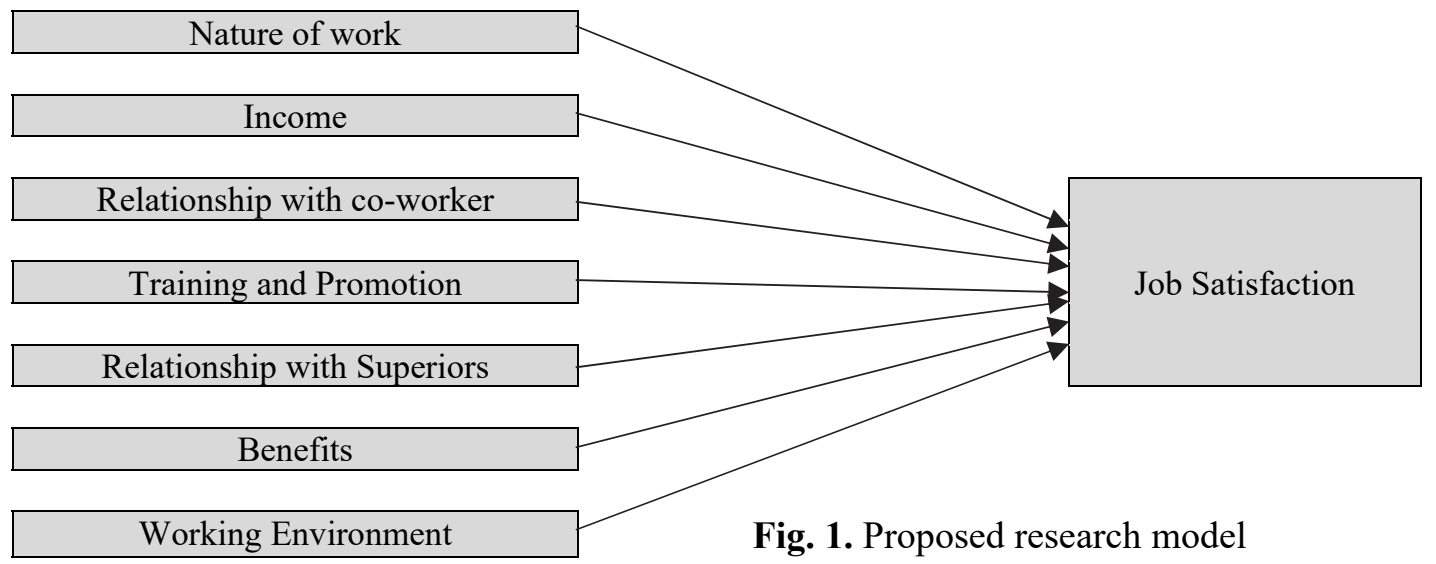

From the research model, the author gives hypotheses from $\mathrm{H}_{1}$ to $\mathrm{H}_{7}$ as follows:

$\mathrm{H}_{1}$ : The nature of work positively affects employees' job satisfaction. 
$\mathrm{H}_{2}$ : Income has a positive relationship with the employee's job satisfaction.

$\mathrm{H}_{3}$ : The co-worker factor contributes to increase employee's job satisfaction.

$\mathrm{H}_{4}$ : Training and promotion opportunities help to improve employee's job satisfaction.

$\mathrm{H}_{5}$ : Superoors factor has an impact on employee's job satisfaction.

$\mathrm{H}_{6}$ : Benefits contribute to increased employee's job satisfaction.

$\mathrm{H}_{7}$ : The working environment has a positive relationship with the employee's job satisfaction.

\section{Research method}

\subsection{Research data}

The author has conducted a sample survey by issuing 330 questionnaires to the officers and employees currently working in the above auditing companies, branches. Hanoi city area. The results obtained 316 votes. After performing the checking and removal of unsatisfactory survey forms, there are 310 valid surveys, meeting the size of the research sample. Factors as well as questionnaires are designed based on different research results at home and abroad in recent years; At the same time, receiving the advice and suggestions of 10 experts who are managers at audit companies, audit lecturers at universities. The scale in the study is a 5-point Likert scale from disagree to completely agree (1 point corresponds to the answer is Totally disagree; 2 points corresponding to the answer is disagree; 3 points for Normal / neutral answer; 4 points for Agree; 5 points for Strongly agree) for questions related to 07 Factors: job nature, income, coworkers factor, training and promotion opportunities, Relationship with Superiors, benefits, work environment.

\subsection{Research method}

In this study, the author applies a mixed research method combining qualitative and quantitative research. In which, qualitative research is a method of in-depth interview by discussion with qualified and experienced experts. For quantitative research methods, it is conducted through the collection of questionnaire survey data and processed by SPSS software to analyze data using the following techniques: Descriptive analysis, Cronbach's Alpha test, EFA exploratory analysis, multiple regression analysis.

Dependent variable: Job satisfaction of officials and employees currently working in audit firms in Hanoi. Independent variables: Relevant factors as shown in Fig. 1.

Research model: $S A T=\alpha_{0}+\alpha_{1} X_{1}+\alpha_{2} X_{2}+\ldots+\alpha_{7} X_{7}+e_{i}$,

where, SAT: General satisfaction of public officials staff currently working at audit firms in Hanoi; $X=\{X 1, \ldots, X 7\}$ : Factors scale variables affecting SAT; $\alpha=\{\alpha 0, \ldots, \alpha 7\}$ : Regression coefficient affects the SAT; ei: error.

\section{Research Results}

\subsection{Scale test}

The results of evaluating the reliability of the scale by Cronbach's Alpha showed that all scales had reliability greater than 0.6 and total variable correlation coefficient greater than 0.3 . All scales satisfy the conditions to analyze discovery factors EFA. The reliability of the scales is summed up in the table below.

Table 1

Test results of the scale

\begin{tabular}{|c|c|c|c|c|c|}
\hline No. & Variable name & Symbols & $\begin{array}{c}\text { Number of } \\
\text { observed variables }\end{array}$ & Cronbach's Alpha & $\begin{array}{c}\text { Coefficient total variable } \\
\text { correlation coefficient }\end{array}$ \\
\hline 1 & Job nature & WO & 4 & $0.786(\mathrm{~min})$ & 0.540 \\
\hline 2 & Income & IN & 4 & 0.880 & 0.675 \\
\hline 3 & Co-workers & $\mathrm{CO}$ & 4 & 0.894 & 0.698 \\
\hline 4 & Work environment & $\mathrm{EN}$ & 4 & 0.740 & 0.513 \\
\hline 5 & Benefits & $\mathrm{BE}$ & 4 & 0.872 & 0.688 \\
\hline 6 & Relationship with Superiors & SU & 4 & 0.729 & 0.468 \\
\hline 7 & Training and advancement opportunities & PR & 4 & 0.741 & 0.503 \\
\hline 8 & Job satisfaction & SA & 3 & 0.739 & 0.500 \\
\hline
\end{tabular}

\subsection{Explore factor analysis EFA}

Factor analysis was performed with Principle Component extraction, Varimax rotation for the dependent observed variable. The results showed that the coefficient $\mathrm{KMO}=0.808$ (meet the condition $>0.5$ ); Significance level and Bartlett test $=0.000(<0.05$ ) shows that the EFA analysis is appropriate. The total extracted variance is $67.989 \%>50 \%$; and factor load factors are greater than 0.5 should meet the requirements. The official scale after handling EFA includes 24 observed variables as proposed. 


\section{Table 2}

Results of factor analysis to discover EFA independent variables

\begin{tabular}{|c|c|c|c|c|c|c|c|}
\hline & \multicolumn{6}{|c|}{ Factor } & \\
\hline & 1 & 2 & 3 & 4 & 5 & 6 & \\
\hline $\mathrm{CO} 4$ & 0.837 & & & & & & \\
\hline $\mathrm{CO} 2$ & 0.825 & & & & & & \\
\hline $\mathrm{CO} 3$ & 0.778 & & & & & & \\
\hline $\mathrm{CO} 1$ & 0.770 & & & & & & \\
\hline BE3 & & 0.760 & & & & & \\
\hline BE4 & & 0.757 & & & & & \\
\hline BE1 & & 0.824 & & & & & \\
\hline BE2 & & 0.812 & & & & & \\
\hline EN1 & & & 0.729 & & & & \\
\hline EN2 & & & 0.714 & & & & \\
\hline EN3 & & & 0.704 & & & & \\
\hline EN4 & & & 0.619 & & & & \\
\hline IN4 & & & & 0.903 & & & \\
\hline IN3 & & & & 0.825 & & & \\
\hline IN2 & & & & 0.818 & & & \\
\hline IN1 & & & & 0.797 & & & \\
\hline SU3 & & & & & 0.840 & & \\
\hline SU1 & & & & & 0.663 & & \\
\hline SU2 & & & & & 0.740 & & \\
\hline SU4 & & & & & 0.576 & & \\
\hline WO1 & & & & & & 0.785 & \\
\hline WO3 & & & & & & 0.722 & \\
\hline WO2 & & & & & & 0.695 & \\
\hline WO4 & & & & & & 0.671 & \\
\hline PR1 & & & & & & & 0.601 \\
\hline PR4 & & & & & & & 0.701 \\
\hline PR3 & & & & & & & 0.824 \\
\hline PR2 & & & & & & & 0.738 \\
\hline
\end{tabular}

Results analysis of the correlation matrix Pearson shows the correlation coefficients are standard statistical significance (Sig. $<0.01)$. Therefore, all variables will be used in regression analysis.

\subsection{Regression analysis}

\section{Table 3}

The results of statistical values of factors affecting job satisfaction of employees' accountant, auditors

\begin{tabular}{|c|c|c|c|c|c|}
\hline Model & $\mathrm{R}$ & R-Square & R-Squared adjusted & Sai estimate of standard deviation & coefficient Durbin - Watson \\
\hline 1 & 0821 & 0673 & 0666 & 0.53417 & 1714 \\
\hline
\end{tabular}

R-squared adjustment reflects the degree of influence of the independent variables on the variation of the dependent variable, in this case 7 factors (Training and advancement opportunities, Co-workers, Income, Nature of work, Work environment, Benefits, Relationship with Superiors) affects $66.6 \%$ of job satisfaction. Factors other than the model and random error affect $33.4 \%$ on the factor of job satisfaction. The Durbin-Watson coefficient lies at 1.714 , in the range from 1.5 to 2.5 , so there is no first order sequence autocorrelation. In order to check whether this regression model is suitable for the collected data set and has application significance, the author continues to test the model's suitability through ANOVA test as follows:

\section{Table 4}

Suitability test (ANOVA)

\begin{tabular}{|c|c|c|c|c|c|c|}
\hline Model & & Sum of Squares & $\mathrm{df}$ & Mean Square & $\mathrm{F}$ & Sig. \\
\hline \multirow[t]{3}{*}{1} & Regression & 177.638 & 7 & 25.377 & 88.937 & 0.000 \\
\hline & Residual & 86.171 & 302 & 0.285 & & \\
\hline & Total & 263.808 & 309 & & & \\
\hline
\end{tabular}

Sig accredited $\mathrm{F}=0.000<0.05$ so the regression model evaluates the degree of influence of 7 factors (Training and promotion opportunities, Co-workers, Income, Nature of work, Work environment, benefits), to the satisfaction of accountants, audit. The 
H. T. Nguyen /Accounting 7 (2021)

model's F-statistic has the value Sig. $=0.000<0.05$ indicates that the model is suitable for the data set and can be deduced overall. VIF coefficients are all less than 2, so there is no multicollinearity phenomenon between the components that does not appear in the research model. The regression results show that the influence of 7 factors on the satisfaction of accountants and auditors at auditing firms in Hanoi is shown in the table below:

\section{Table 5}

Results of multiple regression with partial regression coefficients in the model

\begin{tabular}{|c|c|c|c|c|c|c|c|c|}
\hline & & \multicolumn{2}{|c|}{ Unstandardized } & \multirow{2}{*}{$\begin{array}{c}\text { Standardized } \\
\text { Beta }\end{array}$} & \multirow[t]{2}{*}{$\mathrm{t}$} & \multirow[t]{2}{*}{ Sig. } & \multicolumn{2}{|c|}{ Collinearity Statistics } \\
\hline \multicolumn{2}{|c|}{ Model } & $\mathrm{B}$ & Std. Error & & & & Tolerance & VIF \\
\hline \multirow[t]{8}{*}{1} & (Constant) & 0.010 & 0.235 & & 0043 & 0.965 & & \\
\hline & Nature of Work & 0.143 & 0.048 & & 3.557 & 0.000 & 0.172 & 1.500 \\
\hline & Income & 0.031 & 0.037 & & & 0.000 & 0.031 & 1.265 \\
\hline & Co-worker & 0.869 & 0.040 & 0.104 & 2.164 & 0.000 & & 0.087 \\
\hline & Work environment & 0.082 & 0.049 & 0.068 & 1.683 & 0.000 & 0.654 & 1.530 \\
\hline & Benefits & 0.005 & 0.055 & 0.004 & 0.089 & 0.000 & 0.956 & 1.193 \\
\hline & Relationship with Superiors & 0.098 & 0.122 & 0.157 & 2.168 & 0.000 & 0.726 & 1,937 \\
\hline & Training and promotion & 0.116 & & 0.013 & 0.140 & 0.000 & & 0.016 \\
\hline
\end{tabular}

a. Dependent Variable: Job satisfaction

The regression model is written as:

$Y=0.01+0.143 X_{1}+0.031 X_{2}+0.104 X_{3}+0.068 X_{4}+0.004 X_{5}+0.157 X_{6}+0.013 X_{7}+e$

In which: $\mathrm{Y}$ is the satisfaction with the job

$\mathrm{X}_{1}$ : The nature of the job; $\mathrm{X}_{2}$ : Income; $\mathrm{X}_{3}$ : Colleagues; $\mathrm{X}_{4}$ : Working environment; $\mathrm{X}_{5}$ : Benefits; $\mathrm{X}_{6}$ : Leadership; $\mathrm{X}_{7}$ : Training and promotion opportunities; E: Residual

Fig. 1 shows the histogram of normalized residual frequency chart where the mean is very small mean close to $0($ Mean $=3.99$ $\mathrm{E}-15)$ and standard deviation is also close to 1 (0.989). Thus, the normal distribution of the remainder is not violated.

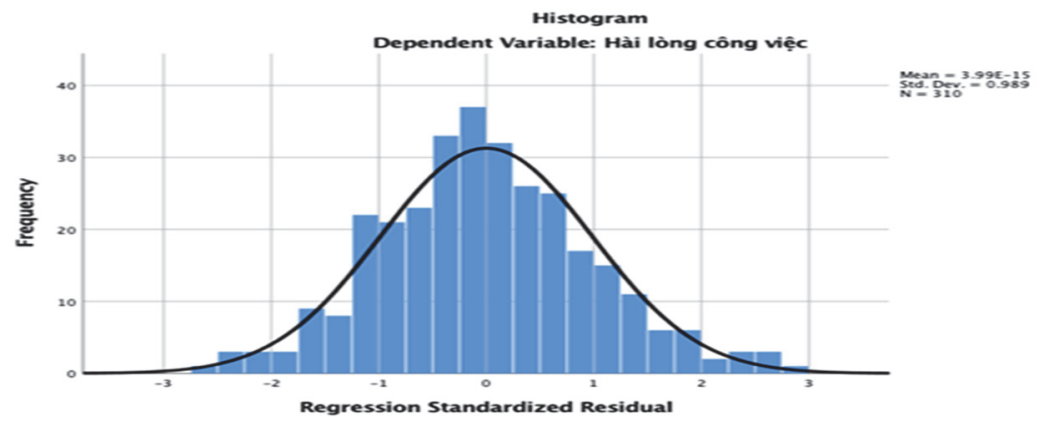

\section{Discussion and recommendations}

Fig. 1. Distribution of residuals

\subsection{Discussion}

Based on the results of quantitative research on factors affecting job satisfaction of accountants and auditors at auditing firms in Hanoi, some conclusions can be drawn. Following:

Multiple linear regression equation extracted according to normalized Beta coefficient shows that leadership factor has higher standardized Beta coefficient (0.157) than all other factors. The standardized Beta coefficients of the remaining factor are: Job nature (0.143), Income (0.031), Co-worker (0.104), Work environment (0.068), welfare (0.004), opportunity Training and promotion (0.013). Thus, the nature of work, relationships with leaders in the working process are the most influencing factors on the satisfaction of accountants and auditors in Auditing firms in Hanoi. This may explain that, for the specifics of the audit, the nature of the work; Strict compliance with the audit program, the direction of the unit's leadership is very important. The assignment and direction clearly, transparently, and fairly will create comfort and greatly affect the satisfaction of employees in the working process, which directly affects the quality of the public job.

\subsection{Recommendation}

From the research results of factors affecting the job satisfaction of accountants and auditors at auditing firms in Ha Noi, the author gives some recommendations to improve the level of job satisfaction, thereby improving the work quality of the accountants and auditors at the Hanoi auditing firms as follows: 
Regarding the working environment: to improve the quality of the working environment Job, auditing firms need to reduce work pressure and appropriately allocate personnel to each job, develop adequate supportive policies and rewards. Improving the quality of the working environment plays an essential role in the satisfaction, quality of work and long-term ability to stay with the company.

Relationship with co-worker: Auditing companies need to create a friendly and fair working environment, policies to encourage employees to work and coordinate together to complete their jobs.

Regarding training and promotion opportunities: Auditing companies need to pay attention to training and career advancement for employees. Because, when receiving vocational training, skills and knowledge, employees will feel they are concerned and trusted and that is the driving force for them to become more and more satisfied and engaged with the organization.

Income: To improve income, auditing firms need to develop a fair and reasonable salary, bonus and allowance policy. Increase income and promotion opportunities for employees based on years of experience and dedication.

With the characteristics of audit, the necessary and most important condition to improve service quality and reputation, the brand of the unit is the human issue, the staff. Once the staff of the unit is satisfied with the job, productivity and efficiency, the quality of the unit's work will constantly increase.

\section{References}

Alam, S. M. T. (2012). Factors affecting job satisfaction, motivation and turnover rate of medical promotion officer (MPO) in pharmaceutical industry: A study based in Khulna city. Asian Business Review, 1(2), 126-131.

Bowling, N.A., Eschleman, K.J., \& Wang, Q. (2010). A meta - analytic examination of the relationship between job satisfaction and subjective well - being. Journal of Occupational and Organizational Psychology, 83, 915-934.

Iaffaldano, M.T., \& Muchinsky, P.M. (1985). Job satisfaction and job performance: a meta-analysis. Psychological Bulletin, 97, 251-273.

Malik, M.E., Nawab, S., \& Naeem, B. (2010). Job satisfaction and organizational commitment of university teachers in public sector of Pakistan. International Journal of Business and Management, 5(6), 17-26.

Parvin, M. M., \& Kabir, M. N. (2011). Factors affecting employee job satisfaction of pharmaceutical sector. Australian Journal of Business and Management Research, 1(9), 113.

Phan, T. M. L. (2011). Analysis of the factors influencing job satisfaction of the commercial banks' staff in Thua Thien-Hue province. Journal of Science and Technology, University of Da Nang, 3, 44.

Yadav, R. K., \& Dabhade, N. (2013). A case study with overview of job satisfaction. Indian Journal of Economics and Development, 1(8), 136-146.

Smith, P.C., Kendall, L.M., \& and Hulin, C.L. (1969). The measurement of satisfaction in work and retirement: A strategy for the study of attitudes. Chicago, Rand McNally.

Spector, P. E. (1997). Job satisfaction: Application, assessment, causes, and consequences (Vol. 3). Sage publications.

Tran Kim Dung (2005). Measuring job satisfaction under Vietnamese conditions. Journal of Scientific Development, 8, 1-9.

Weiss, D. J., Dawis, R. V., England, G. W., \& Lofquist, L. H. (1967). Manualfor the Minnesota Satisfaction Questionnaire. Minneapolis: University of Minnesota.

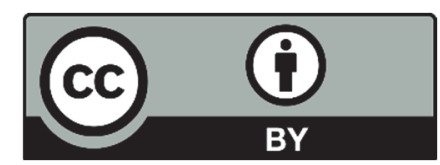

(C) 2021 by the authors; licensee Growing Science, Canada. This is an open access article distributed under the terms and conditions of the Creative Commons Attribution (CC-BY) license (http://creativecommons.org/licenses/by/4.0/). 